DOI: $10.2478 / \mathrm{v} 10122-010-0015-9$

\title{
NOTES ON ALLITERATION IN THE POETIC EDDA
}

\author{
TADAO SHIMOMIYA
}

\begin{abstract}
Tadao Shimomiya. Notes on Alliteration in the Poetic Edda. Lingua Posnaniensis, vol. LII (2)/2010. The Poznań Society for the Advancement of the Arts and Sciences. PL ISSN 0079-4740, ISBN 978-83-7654-078-8, pp. 79-84

The Berlin Anglicist and linguist Martin LeHnERT (1955: 33) says that there are some 30,000 alliterative lines in Old English, 7,300 Eddic long lines, 6,000 and 335 in Old Saxon (Heliand and Genesis) and 200 in Old High German (Hildebrandslied, Muspilli etc.). The following contains some notes on alliteration in the Poetic Edda. The three main types of alliteration ([a] for alliterating, $[\mathrm{x}]$ for not alliterating stave) are $[\mathrm{aa} / \mathrm{ax}][\mathrm{ax} / \mathrm{ax}]$ and $[\mathrm{xa} / \mathrm{ax}]$. There are, however, a number of cases where the principal stave (Hauptstab, hǫfuðstafr, Snorri Sturluson, c.1220, quoted from A. Heusler 1918-1919, §35) is not in the normal place. Moreover, there are also several lines where no alliteration is available, and where, although I am not a medieval Icelandic poet, I would compose the line to make it more alliterative. Toward the end of the article is given a select list of 50 alphabetically arranged alliterations from the Poetic Edda.
\end{abstract}

Tadao Shimomiya, Tokorozawa City, Kamiarai 4-73-24, Japan 359-1142

1. There are three main types of alliteration (abbreviated [a], non alliterating [x]) in a long line of the Poetic Edda, as in other Germanic languages. The first stressed word of the second half-line (second hemistich) decides the alliterating consonant or vowel, which is called principal stave (Hauptstab, họfuðstafr, Heusler §35).

[aa/ax] sól varp sunnan, / sinni mána (Vsp.5) the sun, the companion of the moon, threw (her rays) from south.

[ax/ax] unz prjár kvómo, / pursa meyiar (Vsp.8) until three girls of giants came.

[xa/ax] ek sá Baldri, / blóogom tívur (Vsp.31) I saw for Baldr, for the bloody god.

Vowels can alliterate with any vowel, as in other Germanic languages, on assumption that a glottal stop preceded an initial vowel (word or syllable), as it is still seen in modern German 'auf 'einer 'alten 'Eiche (on an old oak).

[aa/ax] ek man iọtna, / ár um borna (Vsp.2) I remember the giants who were born long ago.

[ax/ax] alda bornom, / orlog seggia (Vsp.20) for the children of men, the fate of men (acc.).

[xa/ax] hittoz æsir / á Iðavelli (Vsp.7) the gods met on Idavoll Plain. 
Consonant clusters sk, sp, st can alliterate only with sk, sp, st.

(7) [aa/ax] skeggọld, skálmọld, / skildir ro klofnir (Vsp.45) axe-age, sword-age, shields are split asunder. [ro=ero]

(8) $\quad[\mathrm{ax} / \mathrm{ax}]$ spakr potti mér / spillir bauga (Fm.32) the breaker (and bestower) of rings (prince) would seem wise to me.

(9) $\quad[\mathrm{xa} / \mathrm{ax}]$ mér hefir stillir / stefnt til eyrar (HHv.33) the prince has challenged me to an island duel.

Types like [aa/xa] (the key word, the first stressed syllable of the second half-line, does not alliterate with any of the other three) can be allowed (Heusler §36).

[aa/xa] brœðr bergrisa, / peim erom bornar (Grt.9) mountain-giants' brothers, we are descended from them.

[ax/xa] heima letia / ek mynda Heriafoðr (Vm.2) I would keep the Father of armies at home. If one reads 'Heria। foðr, then the type is [ax/ax].

[xa/xa] segðu mér ór helio / ek man ór heimi (Bdr.6) tell me the news from the hell, I know the news from the world.

Parallel alliterations of the type $[\mathrm{ab} / \mathrm{ab}]$ or crossed alliterations [ab/ba] are also found:

[ab/ab] ef ek minn hamar / mæettak hitta (Prk.3) if I could find my hammer. [ab/ba] sendi Atli / áro sína (Od.25) Atli sent his messengers.

The following (15) is an example of [aa/aa].

(15) [aa/aa] sumir úlf sviðo, / sumir orm sniðo (Br.4) some roasted wolf, some cut serpent into pieces. If one contrasts úlf (wolf) and orm (serpent) and stresses these words (no stress on sumir), then the type is [ab/ab].

2. There are a number of irrregularities or exceptions. Occasionally initial $h$ is disregarded in $\mathrm{ON}$ and $\mathrm{OE}$ (Heulser §27).

(16) pogðo allir, / hugðo at ráðom (Sg.50) 'all were silent, they considered what to say' ( $h$ in hugðo is ignored). In cases like

(17) Ask veit ek standa, / heitir Yggdrasill (Vsp.19, I know that an ash-tree stands called Yggdrasil), the last word should be read ' Ygg | drasill (then the alliteration pattern is $[\mathrm{ax} / \mathrm{ax}])$. The same is with

(18) ofrgiold fá / gumna synir (Rm.4, the sons of men get a terrible requital), where the alliteration pattern is [xa/ax]. In

(19) bá var hvívetna / vilmál talið (Br.12, then pleasant words in everything were spoken), if one pronounces ' hví । vetna (in everything, dat.), then it can alliterate with vilmál (pleasant words).

No alliteration is available in the following cases.

(20) Rístu nú, Skírnir, / ok gakk at beiða (Skm.1, Get up now, Skirnir, and go to ask);

(21) veiztattu fyrir gorla (Hrbl.4, you don't know clearly what is before you; shorter line of the song form);

(22) Svaf vætr Freyia / átta nóttom (Prk.28, Freyia did not sleep for eight nights). Instead of svaf vætr, svaf ekki (slept not) could make the line alliterating with átta. (Heusler §27.3. admits [vætr : átta] because of half vocalic pronunciation of $v$ ). 
Pronouns, otherwise unstressed as function words, might be contextually stressed as in

In ljóðaháttr (song form) the stanza consists of two long lines with caesura, alternating with two lines containing three stresses and no caesura.

Bú er betra, / pótt lítit sé (Háv.36, 37, A farm of your own is better, even if small) has no alliteration available connecting the first and the second halflines. Instead of bú (farm) couldn't one use lendur (land, estate, Ländereien, praedia, Möbius) alliterating with the adjective fem.pl.litlar?

3. In the Poetic Edda there are not many alliterating set phrases like slow and steady or Land und Leute. One finds better examples in Old Norse proverbs (NYGAARD), as for example, Af hreinu bergi kemr hreint vatn (from a clean mountain comes clean water), Eigi fellr tré við fyrsta hogg (no one fells a tree with the first stroke), Fyrsti fugl foer fyrsta korn (the first bird gets the first grain), Lik born leika bezt (like children play best), Opt kemr skin eptir skúr (sunshine often comes after a shower), Ván er vakandi manns draumr (hope is the dream of a man who is awake), down to modern times, as in Danish Få er som far, ingen som mor (a few are like father, no one is like mother), Gode ord er bedre end guld (good words are better than gold). Odin has many names like Al-foðr (father of all) and Alda-foðr (father of men), which can alliterate with Odin, but there is not a line where the two words stand together. 
4. Eight best things are named in Grm.44. Grm. [=Grimnir 'the Masked One'] is Odin.

Askr Yggdrasils, hann er œztr viða, enn Skíðblaðnir skipa,

Óðinn ása, enn ióa Sleipnir,

Bilrǫst brúa, enn Bragi skálda,

Hábrók hauka, enn hunda Garmr.
The ash of Yggdrasil is the noblest of trees, and Skidbladnir the best of ships, Odin is the best of gods, Sleipnir of horses, Bilrost is best of bridges, Bragi of poets, Habrok is best of hawks, and Garm of dogs.

When is the best thing tried? Hávamál 81 tells when it is tried.

At kveldi skal dag leyfa, kono, er brend er,

maki, er reyndr er, mey, er gefin er,

ís, er yfir kømr, ol, er drukkit er.
At evening the day should be praised, the woman when she is burned (is dead), the sword when it is tested, the girl when she is married, the ice when one goes over it, beer when it is drunk.

5. Below is given a select list of fifty examples of alliteration in the Poetic Edda (alphabetically arranged).

1. alsnotra ambót (Prk.26) the very shrewd maid [=Loki]

2. Ask...heitir Yggdrasill (Vsp.19) an ash-tree called Yggdrasil [=the world tree]

3. Ask ok Emblo, orloglausa (Vsp.17) Ask and Embla [=the first man and woman], [still] fateless (acc.)

4. bar hana bióri (Vkv.28) [he] overcame her with beer.

5. biorg brotnoðo (Prk.21) the mountains split asunder.

6. biórsalr...Brimir (Vsp.37) beer hall of Giant Brimir.

7. bregða blunnstofom (Sd.2) [I could not] break the slumber-spells.

8. Brynhildr...brúðr (Grp.45) Brynhild the bride.

9. deyr fé, deyia frændr (Háv.77) cattle die, kinsmen die.

10. dimmi dreki (Vsp.66) the dark dragon.

11. dreymði dróttláta (Am.10) the courtly lady had a dream (fem.acc.)

12. drukko ok dœmðo degr mart (Sg.2) [they] drank and talked for many days.

13. drykk ins dýra miaðar (Háv.105, 140) a drink of the precious mead.

14. dverga dróttin (Vsp.9) the king of the dwarfs (acc.)

15. alla forsar (Vsp.59) waterfalls fall.

16. fen fioturs (Vkv.24) mud of fetters.

17. fiall farið...(Háv.3) [he] has come over the mountain.

18. freista frama (Háv.2) seek one's luck.

19. Frigg ok Freyia ok fleiri goð (Od.9) Frigg and Freyia and more gods.

20. gap ginnunga...gras (Vsp.3) yawning gap [and] grass [nowhere].

21. Glaðsheimr...gullbiarta (Grm.7) Gladsheim...the gold-bright [Valhalla stands]

22. grét Guðrún, Giúka dóttir (Gðr.I.16) Gudrun wept, Giuki’s daughter.

23. gull á Gnitaheiði (Akv.6) gold on Gnita-heath [=home of the dragon Fafnir]

24. Gunnari Gotna drótti (Grp.35) for Gunnar, king of the Goths.

25. hálfom hleif (Háv.52) [even] with half a loaf [one can get a friend] 
26. harðan Hunding (HH.10) Hunding the hard (acc.) [=the enemy of Volsung]

27. harðast harma minna (Ghv.16) the cruellest of my griefs.

28. Hel hafi! (Fm.21) Hel [Goddess of Death] take you! [Russians say Devil take you!]

29. hiarðar heim skolo (Háv.21) cattle should go home [they know the time when].

30. hló pá Atla hugr (Gðr.III.10) then Atli’s heart laughed.

31. í holt Hoddmimis (Vm.45) [the first man and woman in the new world will hide] in Hoddmimir's wood.

32. krásir...konor (Prk.24) the dainties [are] for the women.

33. kunningri kono (Vkv.25) to the cunning queen.

34. lopt ok logr (Skm.6) [all] sky and sea [shone]

35. lundr lognfara (Skm.41) quiet grove [where Frey and his lady Gerd are to meet]

36. long ero lýða læ (Sd.2) long are the woes of the people.

37. maðr mæztr (Grp.7) the most glorious man.

38. mey ok mog vaxa saman (Vm.33) a girl and a boy (acc.) grow together.

39. miðgarð mœran (Vsp.4) the great Midgard (acc.the world of mankind)

40. ofdrykkia ǫls (Háv.11) too much beer drinking.

41. ósánir akrar... (Vsp.62) unsown fields [will grow in the new world]

42. Reginn...ræðr (Fm.33) Regin will betray.

43. sól tér sortna, sígr... (Vsp.57) the sun blackens, [the earth] sinks [into the sea]

44. stund er til stokksins, onnor til steinsins (Hrbl.56) one hour to the stock, another to the stone, cf.G.über Stock und Stein, KHM 57)

45. Svanhildr, sólar geisla (Sg.55) Svanhild, [brighter] than the sunshine.

46. vá Valhallar...vitoð... (Vsp.33) woe of Valhalla, do ye know?

47. vápndauða vera (Grm.8) those fallen in the battle (acc.).

48. vargr á viðom (HH.II.33) wolf in the forest.

49. vindold, vargold...verold... (Vsp.45) wind-age, wolf-age, [before] the world [ruins]

50. ql með mọnnom, enn með ásom biórr (Alv.34) [it is called] ale among men, and beer among gods [men's language and gods' language were different].

\section{ABBREVIATIONS OF THE POEMS OF THE ELDER EDDA}

Akv. = Atlakviða in grœnlenzka (The Lay of Atli); Alv. = Alvíssmál (All-Wise’s Sayings); Am. = Atlamál in grœnlenzko (The Greenlandic Poem of Atli); Bdr. = Baldrs draumar (Bardr's Dreams); Br. = Brot af Sigurðarkviðo (Fragment of a Poem about Sigurd); Fm. = Fáfnismál (The Lay of Fafnir); Gðr.I. = Guðrúnarkviða in fyrsta (The First Lay of Gudrun); Gðr.III. = Guðrúnarkviða in priðia (The Third Lay of Gudrun); Ghv. = Guðrúnarhvǫt (The Whetting of Gudrun); Grm. = Grímnismál (Grimnir's Sayings); Grp. = Grípisspá (Gripir's Prophecy); Grt. = Grottasǫngr (The Song of Grotti); Háv. = Hávamál (Sayings of the High One); HH. = Helgakviða Hundingsbana in fyrri (The First Poem of Helgi Hundingsbani); HHv. = Helgakviða Hiǫrvarðzsonar (The Poem of Helgi Hiorvardsson); HH.II. = Helgakviða Hundingsbana onnor (A Second Poem of Helgi Hundingsbani); Hrbl. = Hárbarðzlióð (Harvard's Song); Hunn. = Hunnenschlachtlied (The Lay of the Fight of the Huns); Od. = Oddrúnargrátr (Oddrun's Lament); Rm. = Reginsmál (The Lay of Regin); Sd. = Sigrdrífomál (The Lay of Sigrdrifa); Sg. = Sigurðarkviða in skamma (A Short Poem about Sigurd); Skm. = For Skírnis (Skirnir's Journey); Vkv. = Vọlundarkviða (The Lay of Volund); Vm. = Vafðrúðnismál (Vafthrudnir's Sayings); Vsp. = Vọlospá (The Seeress's Prophecy); Prk. = Prymskviða (Thrym's Poem) 


\section{REFERENCES}

Bellow Henry Adams (tr.). 1923. The Poetic Edda. New York: The American-Scandinavian Foundation. (Dover Publications, New York, 2004 contains the first part, Lays of the Gods, only).

Gering Hugo. 1892. Die Edda. Übersetzt und erläutert von Hugo Gering. Leipzig und Wien (Meyers KlassikerAusgaben in 150 Bänden).

Gering Hugo. 1903. Vollständiges Wörterbuch zu den Liedern der Edda. Reprint Hildesheim 1971.

Gordon E.V. (second edition revised by A.R. Taylor, 1957). An Introduction to Old Norse. Oxford University Press.

Heusler Andreas. 1918-1919. "Stabreim.” In: Hoops 1918-1919: 231-240.

Hoops Johannes (ed.). 1918-1919. Reallexikon der germanischen Altertumskunde. Bd. 4. Strassburg.

KuHn Hans (ed.). 1962-1968. Edda. Die Lieder des Codex regius nebst verwandten Denkmälern. I. Text. Dritte, umgearbeitete Auflage. II. Kurzes Wörterbuch. Heidelberg: Carl Winter.

La Farge Beatrice, Tucker John (eds.). 1992. Glossary to the Poetic Edda. Heidelberg: Carl Winter.

Larrington Carolyne (trans.). 1999. The Poetic Edda. Oxford: The World's Classics. [The translation is text faithful and reader friendly].

LeHNERT Martin. 1955³. Altenglisches Elementarbuch. (Sammlung Göschen Bd. 1125). Berlin: Walter de Gruyter. [Prof. Lehnert (1910-1992) of Humboldt-Universität zu Berlin was one of my first teachers through books which taught me what Germanic and historical linguistics is].

MöBIUs Theodor. 1963. Altnordisches Glossar. Darmstadt: Wissenschaftliche Buchgesellschaft (reprint of Leipzig 1866).

NygaARD Marius. 1964. Gammelnorsk lesebok for gymnasiet. 16de utgave ved Trygve Knudsen. Bergen. Ed. B.Giertsen.

RANKE Friedrich. 1937. Altnordisches Elementarbuch. (Sammlung Göschen Bd. 1115). Berlin und Leipzig: Walter de Gruyter.

Ranke Friedrich, Hofmann Dietrich. 1967. Altnordisches Elementarbuch. (Sammlung Göschen Bd.1115/a/b) Berlin: Walter de Gruyter.

Shimomiya Tadao (forthcoming). Alliteration in the Poetic Edda.

Simrock Karl. 1987. Die Edda. Essen, Phaidon Verlag, 2.Aufl. The first edition of Simrock's translation is 1851. VRIES Jan de. 1962. Altnordisches etymologisches Wörterbuch. 2.Aufl. Leiden: E.J. Brill. 